\title{
Implementation of the Role of Mayor Expert Staff in Supporting Strengthening Policy Analysis in Government Bandung
}

\author{
Iwan Satibi*, Ediyanto, Ahtu Duriat \\ Fakultas Ilmu Sosial dan Ilmu Politik \\ Universitas Pasundan \\ Bandung, Indonesia \\ *iwan.satibi71@gmail.com
}

\begin{abstract}
Policy analysts hold important positions in government. One of the causes of failure to develop superior public policies is the absence of policy analysts in the government, or they are there but do not work well, or if they are already working well, they are unable to produce great policies. In Bandung City Government, the role of policy analyst is assumed by the Bandung Mayor's Expert Staff. The research objective is to describe and analyze the role of the Bandung Mayor's Expert Staff in supporting the strengthening of the role as a policy analyst in the Bandung City Government. This research was conducted using a qualitative approach and descriptive methods, while the data collection techniques used were in-depth interviews, observation and documentation study. The results of the study concluded that the implementation of policies regarding the role of the Bandung Mayor's Expert Staff was not empirically not optimal in supporting policies within the Bandung City Government. The findings are indicated by the absence of an outcome capable of producing strategic policies. The factors that influence the implementation of this policy consist of factors of communication, resources, disposition, bureaucratic structure, and political factors. Important elements contained in these factors, such as elements of clarity of communication, facilities and infrastructure, as well as work procedures guidelines, have not been fulfilled, thus becoming an obstacle to the implementation of this policy.
\end{abstract}

Keywords—expert staff, policy analyst, policy implementation

\section{INTRODUCTION}

The expert staff of the Governor, Regent and Mayor is a structural position in regional government. Expert staff are appointed and dismissed by the Governor, Regent / Mayor from civil servants, to assist in carrying out their duties. As we all know, Governors and Regents / Mayors as Regional Heads have a central role in government. Therefore, a regional head assistant is needed who can always provide advice and considerations to the Regional Head in dealing with problems in society. Expert staff are positions that carry out the mentoring task.
The position of the Expert Staff of the Regional Head is regulated in the Government Regulation of the Republic of Indonesia Number 41 of 2007 concerning the Organization of Regional Apparatus. Article 36 of the regulation states that the Governor, Regent / Mayor in carrying out their duties can be assisted by expert staff with a maximum number of 5 (five) staff. These expert staff are appointed by governors, regents / mayors from civil servants. The duties of expert staff are determined by the governor, regent / mayor outside of the duties and functions of regional apparatus. Article 37 states that the Governor's Expert Staff is a structural position for echelon IIa, and an expert staff for the Mayor is a structural position for echelon IIb. Expert staff in carrying out their duties are administratively coordinated by the Regional Secretary.

Regulation of the Minister of Home Affairs Number 57 of 2007 concerning Technical Guidelines for Organizational Structuring of Regional Apparatus in the attachment letter G states that expert staff has the task of providing analysis of regional government issues in accordance with their respective areas of duty. In carrying out their duties, expert staff is coordinated by the Regional Secretary. The number and nomenclature of expert staff positions can be adjusted according to the capacity needs of each region. The working relationship between expert staff and SKPD in regional government is in the form of consultation and coordination.

The duties and functions of the Bandung Mayor's Expert Staff are outlined in the Bandung Mayor's Regulation Number 192 of 2011 concerning Main Duties, Functions, Job Descriptions and Work Procedures for the Bandung City Regional Secretariat Organizational Unit. Article 42 paragraph (1) states that the Mayor's expert staff has the duty to assist the Mayor by providing an analysis of governance issues in accordance with the scope of their duties.

In carrying out the main tasks as intended, as stated in Article 42 paragraph (2), the Mayor's Expert Staff shall each have the following functions: (1) To study and identify problems in the implementation of regional government according to the scope of their duties; (2) Collecting data and 
materials related to the subject matter; (3) Analyzing the main problems based on regional policies and laws in force; (4) Compiling conclusions, considerations and suggestions for actions to the Mayor through the Regional Secretary; (5) Preparation of annual report on the implementation of tasks to the Mayor through the Regional Secretariat; and (6) Performing other duties assigned by superiors in accordance with the scope of their duties.

Looking at the description of the main tasks and functions, the Mayor's Expert Staff is a policy analyst for local governments. Nugroho [1] says that: "Policy analyst is an intellectual and practical activity aimed at creating, critically assessing and communicating knowledge about and in the policy process". Nugroho [1] explains that one of the causes of the failure of the government to develop superior public policies is the absence of policy analysts in the government, or they are there but do not work well, or if they are working well they are unable to produce great policies. This statement shows how important the role of policy analysts is in a local government.

Sutarto [2] suggests that in an organization, a staff member has a role as an official in charge of conducting research, analysis, recommendations and advice. Based on this and a description of the function of the Bandung Mayor's Expert Staff, the Mayor of Bandung's Expert Staff has a role as an official in charge of conducting research on problems of local government administration according to the scope of their duties, analyzing the main problems based on regional policies and applicable laws and regulations, as well as providing recommendations and advice in the form of drawing conclusions, considerations and suggestions for actions to the Mayor through the Regional Secretary of the City of Bandung.

Empirically, the position of the Bandung Mayor's Expert Staff is often considered a position to be avoided because of the negative impression attached to it. In the eyes of the public, there is a growing perception that the position of expert staff is a place to accommodate officials who are no longer in use. In addition, there is also a growing perception that expert staff is a temporary place for officials while waiting for their turn to be assigned as head of SKPD in the next rotation and transfer of positions.

\section{REVIEW LITERATURE}

Sutarto [2] suggests that in an organization, a staff member has a role as an official in charge of conducting research, analysis, recommendations and advice. Based on this and a description of the function of the Bandung Mayor's Expert Staff, the Mayor of Bandung's Expert Staff has a role as an official in charge of conducting research on problems of local government administration according to the scope of their duties, analyzing the main problems based on regional policies and applicable laws and regulations, as well as providing recommendations and advice in the form of drawing conclusions, considerations and suggestions for actions to the Mayor through the Regional Secretary of the City of Bandung.

Empirically, the Expert Staff of the Mayor of Bandung has a negative image of the government. This position is often seen as a structural position that should be avoided, because there is a growing perception that the position of expert staff is a place to accommodate officials who are no longer in use. In addition, there is also an assumption that expert staff is a temporary position for officials while waiting for their turn to be assigned as head of SKPD in the next rotation and transfer of positions.

The strength of the assumption that expert staff does not have an important role in the City Government of Bandung illustrates that there is an unattainable goal in the policy regarding the role of the Bandung Mayor's Expert Staff. Soenarko [3] argues that the implementation (implementation) of policy is basically an activity to achieve the goals set out in the government policy. Not much different from that definition, Nugroho [1] explains that: "In principle, policy implementation is a way for a policy to achieve its goals". Based on this theory, when the reality on the ground is inversely proportional to the policy set, it is necessary to ask how the policy is implemented.

Winarno [4] states that in general the term policy or policy is used to designate the behavior of an actor or a number of actors in a certain field of activity. Meanwhile, Wahab [5] emphasizes that policies are actually patterned actions that lead to certain goals and not just random decisions to do something.

According to Purwanto and Sulistyanti [6], the failure or success of implementing a policy in realizing the policy objectives that have been outlined, in the implementation study literature is then conceptualized as implementation performance. Assessment of performance is needed to be able to answer the main questions in implementation studies, namely: (i) what is the content and objectives of a policy; (ii) what steps must be taken to achieve these objectives; and (iii) whether, after these stages were carried out, the implementation carried out was able to achieve the policy objectives or not. To be able to answer these three questions, a logical framework is needed that can help researchers understand policy implementation which is inherently complex. The framework that can be used to see how the implementation performance can be seen from the following figure 1 . 


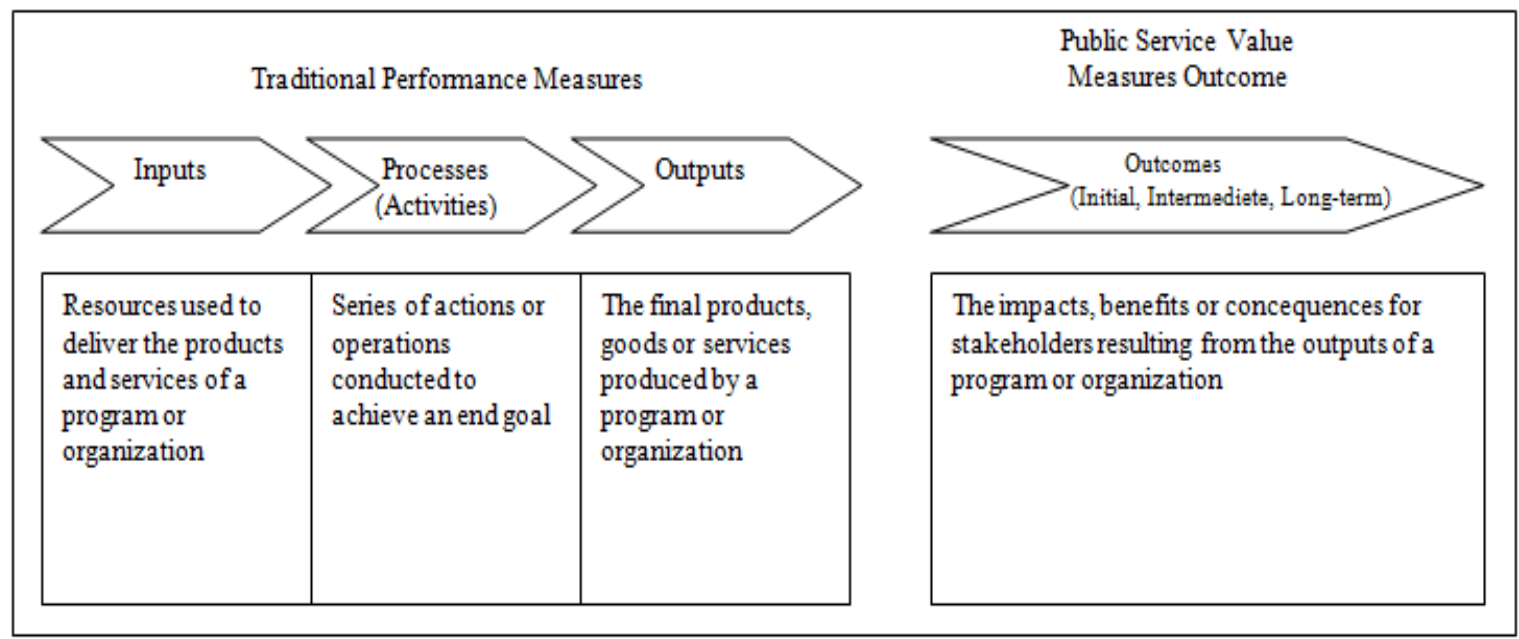

Fig. 1. The framework that can be used to see how the implementation performance [6].

According to Edward [7], in order for policy implementation to be effective, there are four main issues that must be considered, namely: (1) Communication. (2) Resources or resources. (3) Disposition or attitude. And (4) Bureaucratic structures or bureaucratic structures.

\section{RESEARCH METHODS}

In accordance with the context of the above topic, this study uses a qualitative approach, while the research method used is descriptive method. The use of descriptive methods is based on the consideration that descriptive methods are used to describe a condition / symptom, system, current event based on available data and information [8]. The data was collected by using the interview, observation and documentation dept, while the data analysis was carried out using the Miles and Huberman model.

\section{RESULTS AND RESEARCH DISCUSSION}

The results showed that the role of the Bandung Mayor's Expert Staff to place expert staff as policy analysts in the Bandung City Government. Nugroho [1] says that: "Policy analyst is an intellectual and practical activity aimed at creating, critically assessing and communicating knowledge about and in the policy process". The importance of the role of policy analysts is illustrated in the opinion of Nugroho [1] which states that one of the reasons for the failure of the government to develop superior public policies is the absence of policy analysts in the government, or they are there but not working well, or if they have worked with neither is capable of producing great policies. This statement shows how important the role of policy analysts is in a local government.

The reality on the ground shows that the position of the Bandung Mayor's Expert Staff is often considered a position to be avoided because of the negative impression attached to it. In the eyes of the public, there is a growing perception that the position of expert staff is a place to accommodate officials who are no longer in use. In addition, there is also a growing perception that expert staff is a temporary place for officials while waiting for their turn to be assigned as head of SKPD in the next rotation and transfer of positions.

Negative views on the role of the Bandung Mayor's Expert Staff emerged as a result of the absence of significant outcomes or impacts from the implementation of policies on the Role of the Bandung Mayor's Expert Staff, while outcomes can be a benchmark for assessing the performance of implementing a policy, by comparing it with what is the policy objective. This is as the opinion of Purwanto and Sulitsyastuti [6] which states that "... if the policy outcome is able to realize policy objectives, then we can say that the performance of the policy implementation is high".

The absence of a policy outcome in the policy regarding the role of the Bandung Mayor's Expert Staff shows that the policy objectives are not achieved. The failure to achieve policy objectives shows that policy implementation has not been optimal. This is in accordance with Nugroho's [1] statement, that policy implementation is, in principle, a way for a policy to achieve its goals.

To understand the phenomena that occur in policy implementation regarding the Role of Bandung Mayor's Expert Staff, researchers used policy implementation theory according to Edward III [7]. In this context, he said, the success of policy implementation is determined by 4 (four) factors: communication, resources, dispositions or attitudes and the structure of the bureaucracy.

\section{A. Communication}

According to Edward III [7], there are three important things that determine the success of communication in a policy, namely whether the policy is delivered (transmission), whether 
the policy is conveyed clearly (clarity), and whether the policy is delivered consistently (consistency).

The policy on the Role of the Bandung Mayor's Expert Staff has been submitted to the Bandung Mayor's Expert Staff, as well as to the SKPD within the Bandung City Government. The delivery of the policy to the expert staff can be seen from the output in the form of a staff review. The submission of policies to SKPD is carried out through a Circular of the Regional Secretary of Bandung City Number 800/981-Setda dated March 10, 2016.

Even though this policy has been conveyed, it does not mean that there are no obstacles that arise in the implementation of this policy. One of them, not all SKPDs involve expert staff in their activities, even though this has been mandated by the Regional Secretary of Bandung City. Whereas with the involvement of expert staff in SKPD activities, it will facilitate the implementation of the duties of expert staff in analyzing problems that occur in the city of Bandung.

Researchers assess that the reluctance of some SKPDs to involve expert staff in their activities is due to incomplete information conveyed about the role of the Bandung Mayor's Expert Staff. This is supported by the theory put forward by Purwanto and Sulistyastuti [6], that incomplete information results in target groups not being actively involved in policy implementation. According to him, to be able to invite involvement, several stages are needed, namely: awareness, application, acceptance and enrollment. These stages of involvement will only be achieved if complete information is available about the implemented policies.

Purwanto and Sulistyastuti [6] added that another result of inadequate delivery of information is misunderstanding or miss information. This often occurs when policies are not conveyed properly due to: the language used is difficult to understand, the media used to convey policy messages to target groups is not precise, information delivery is one-way-traffic which does not open space for dialogue, and so on. The implication of this miss-information is that the target group is resistant to the policies to be implemented.

Meanwhile, according to Purwanto and Sulistyastuti [6], these three are part of the standard regarding the minimum information that must be submitted to the target group in relation to a policy. If these minimum standards are not met, information delivery will not run well.

The description above shows that policies are not only sufficient to convey, but also must be conveyed clearly. This is in accordance with what was said by Edward III [7], that clarity is the second important factor of communication, which determines the success of communication in a policy. Often the orders given to implementers are vague or unclear, and do not specify when and how these activities should be carried out.

The results of the research findings show that the policy on the role of the Bandung Mayor's Expert Staff has not clearly and in detail explained how the role is implemented technically. There is also no mayor regulation that regulates the work procedure or Standard Operating Procedures (SOP) on how the role of the Bandung Mayor's Expert Staff is implemented.

The absence of work procedures guidelines in the policy regarding the Role of the Bandung Mayor's Expert Staff is a form of discretion, because it is impossible for the Bandung City Government to not know the existence of the interior ministerial circular, so it is negligent and does not make clear procedures regarding the work procedures of expert staff. Discretion or discretion is usually given so that policy implementers can flexibly adjust policy implementation guidelines to the realities encountered in the field. This is consistent with what Edward III [7] said, that obscurity is not always an obstacle to policy implementation, because sometimes implementers need flexibility, and can even be hampered by instructions that are too detailed.

However, discretion in the policy regarding the Role of the Bandung Mayor's Expert Staff has actually become an obstacle to the implementation of this policy. The discretion given in the form of rules that are not too binding actually makes policies not work as they should. Support for the implementation of the roles required by the Expert Staff is even difficult to obtain because there are no rules covering it.

Apart from being clearly conveyed, policies must also be delivered consistently if their implementation is to be effective. Delivery is done clearly but the instructions contradict one another will make it difficult for implementors to implement policies. The policy is conveyed to the Bandung Mayor's Expert Staff and to the related SKPD without any changes or differences in messages, namely that the Expert Staff has an important role in government, as an input for policies to be determined by the Mayor of Bandung.

\section{B. Resource}

The second factor that determines the successful implementation of a policy according to Edward III [7] is the resource factor. Edward III [7] divides resources into 4 (four) important things, namely staff (employees), information (information), authority (authority) and facilities (facilities). The research findings show that the available resources have not supported the implementation of policies regarding the role of the Bandung Mayor's Expert Staff.

There are 2 (two) main points that must be discussed regarding staff, namely the size or number of staff, and the capabilities of the staff. Based on the research findings, the number of expert staff on policy implementation regarding the role of the Bandung Mayor's Expert Staff is in accordance with what is mandated by the policy, namely 5 (five) people.

The data states that the currently serving expert staff have met the requirements to be appointed as echelon II structural officials, as well as people who do have the ability to serve as the Bandung Mayor's Expert Staff. Selected Expert Staff are senior employees who have years of work experience in 
various fields. This work experience and seniority are important in policy implementation. This is in accordance with what Purwanto and Sulistyastuti [6] explained, that work experience and seniority are one of the keys to organizational success in implementing a policy. Work experience and seniority are important assets because employees who have a long work experience naturally have more involvement in implementing various policies.

As explained in Government Regulation Number 13 of 2002, the rank and class / space for echelon IV is the Junior Administrator at TK. I (III / b) for the lowest and the Tk. I (III / c) for the highest rank. Administrators are not just executors. Employees at this level must have a certain scientific field with a deep understanding of the principles of knowledge, in contrast to employees at regulatory level (II) who are more focused on the implementation of technical matters.

Apart from staff resources, information resources are still lacking. Information consists of two forms, namely information on how policies should be implemented and information on the compliance of related parties with existing regulations. Information on how policies should be implemented can be obtained through the formulation of a Standard Operating Procedure (SOP), which until now the Expert Staff of the Mayor of Bandung does not have one. The role of the Bandung Mayor's Expert Staff is only illustrated by the rules regarding the main duties and functions, without any description of how these tasks and functions should be carried out. The policy regarding the role of the Mayor's Expert Staff and orders to involve the Mayor's Expert Staff in official activities has been conveyed by the Regional Secretary through a circular. However, as previously described in the research findings, not all heads of SKPD have complied with these orders.

In carrying out their roles, expert staff certainly need flexibility in many ways. The flexibility or leeway that expert staff have can make expert staff more focused on carrying out their roles without having to think about overly detailed, complicated and binding rules. However, SOPs in carrying out activities are of course still needed. SOP or in other terms a guidebook, according to Sutarto [2] can be used as a guide for officials in doing work properly, so that they can be avoided working only based on the tastes of each official, and doubts, misunderstandings in carrying out work can be avoided. .

The existence of clear information regarding the role of the Bandung Mayor's Expert Staff can actually minimize SKPD non-compliance to involve expert staff in its activities. Because this non-compliance can occur due to the working relationship between the expert staff and SKPD which is still confused. In the Regional Secretary's circular, it was stated that the SKPD was expected to be able to involve the Bandung Mayor's Expert Staff in various activities according to their respective fields of expertise. However, the extent of its involvement and the technicality of its implementation are not clearly described. With the existence of SOPs or clear work procedures regarding the role of expert staff, it can avoid doubts for SKPDs to involve expert staff in their program of activities.
In terms of authority, many powers that are allowed to be owned by expert staff are not stated in the policy on the role of the Bandung Mayor's Expert Staff. For example, in the Circular of the Minister of Home Affairs Number 100/4675 / SJ dated 23 November 2011 regarding the Empowerment of the Capacity of Expert Staff for Regional Heads, it is stated that the expert staff has the authority to initialize the draft official script which is public policy. However, this was not stated in the policy on the Role of Expert Staff for the Mayor of Bandung, so it was never carried out.

Another example, the Bandung Mayor's Expert Staff also does not have the authority to plan capacity building, coaching, coordination and evaluation activities, including in budget planning. In contrast to the authority for affixing initials, the researchers assessed that the authority to plan capacity building, coaching, coordination and evaluation activities including budget planning needs to be owned by the Bandung Mayor's Expert Staff.

The thing that stands out the most in the lack of resources possessed by expert staff is facilities. The Bandung Mayor's Expert Staff as echelon II officials should have received echelon II level facilities. Bandung Mayor's Expert Staff Facilities as structural echelon IIb officials are regulated in Bandung Mayor Regulation Number 014 of 2009 concerning Standardization of Work Facilities and Infrastructure in Bandung City Government. However, based on research findings, the available facilities do not support the implementation of policies regarding the role of the Bandung Mayor's Expert Staff.

The limited facilities provided to expert staff is due to the absence of a special budget for expert staff. To obtain the required facilities, expert staff must wait and share the budget with other needs at the General and Equipment Section of the Bandung City Secretariat. In fact, as stated by Purwanto and Sulistyastuti [6], the amount of budget allocated to a policy or program shows how much political will the government has towards that policy. The amount of the budget can be used as a proxy to see how much commitment the government has on the policy. Hypothetically, it can be said that the greater the budget allocated by the government to a policy, the greater the chance for the successful implementation of the policy, because the government also has a strong commitment so that the policy can be successful.

\section{Disposition}

Disposition or attitude is the next factor that determines the successful implementation of a policy. The research findings show that there is a positive attitude from the Bandung Mayor's Expert Staff to implement policies regarding their roles. The findings of research in the field show the positive attitude of the Mayor of Bandung Expert Staff in carrying out its role as stated in the policy on the role of the Mayor of Bandung Expert Staff.

A negative attitude has even emerged from several SKPDs that have not yet involved the Bandung Mayor's Expert Staff in 
their official activities. This certainly complicates policy implementation regarding the role of the Bandung Mayor's Expert Staff, because in carrying out its role to analyze public policy problems in Bandung City, expert staff certainly need information support from the relevant SKPD.

This negative characteristic can arise because in the bureaucracy, every organizational unit usually has different views on a policy. This is as stated by Edward III [7], that this disagreement hinders cooperation and hinders policy implementation. With respect to a policy, related parties may have different priorities, different commitments and different ways of dealing with a problem. These differences do not allow the creation of mutual trust and close working relationships, which are often needed to achieve effective implementation.

The way to change the attitude of both organizations and individuals towards a policy according to Edward [7] is through incentives. However, it is impossible for this incentive to be used to change the SKPD's view of the policy regarding the role of the Bandung Mayor's Expert Staff. It is impossible for SKPD to be given incentives just to involve expert staff in their activities. The method that can be taken is by explaining the extent of the involvement of the expert staff in the SKPD activities. One of the reasons for reluctance to implement a policy is due to parochialism or a narrow view of something. This view usually arises because of someone's ignorance of it. Misunderstandings most likely arise from ambiguity. With clarity regarding the work relationship and the extent to which expert staff are involved in SKPD activities, it is hoped that the negative nature of SKPD towards policies regarding the role of the Bandung Mayor's Expert Staff will change.

\section{Bureaucratic Structure}

According to Edward III [7], in addition to communication, resources and disposition, the bureaucratic structure is also a determining factor for the effectiveness of implementing a policy. The research findings show that the bureaucratic structure is one of the things that hinders the implementation of policies regarding the role of the Bandung Mayor's Expert Staff. Edward III [7] explained that the bureaucratic structure in policy implementation is divided into two things, namely Standard Operating Procedures (SOP) and fragmentation or division of authority.

Although in theory SOPs were originally designed to facilitate policy implementation, in practice they can also be a hindrance. SOPs can hinder policy implementation by inhibiting change. Designed for specific or typical situations, SOPs can be ineffective in unusual circumstances. Therefore, with regard to policies regarding the role of the Bandung Mayor's Expert Staff, SOPs are not suitable for example regulating how and when analysis of public problems should be carried out by the Bandung Mayor's Expert Staff, because these functions and tasks are situational. As the opinion of Purwanto and Sulistyastuti [6], if the SOP is well prepared and the conditions in the field are in accordance with the SOP that has been compiled, then the implementation will run smoothly.
In a bureaucratic structure, fragmentation can become an obstacle to policy implementation. Fragmentation is a division of responsibilities, and this can make coordination in policy difficult. The resources and authority required to solve problems comprehensively are often scattered across many organizational units. Fragmentation also allows overlapping and duplication of many organizational units.

Related to the concept of fragmentation put forward by Edward [7], the fragmentation that occurs in the policy regarding the role of the Bandung Mayor's Expert Staff does not become an obstacle to policy implementation. Because the division of authority and responsibility in the policy regarding the role of the Bandung Mayor's Expert Staff is in the division of their duties. There are five areas of duty of the Bandung Mayor's Expert Staff, namely Government \& Law, Economics, Regional Finance \& Investment, Development \& Infrastructure, Technology \& Information, and Community \& Human Resources. Each expert staff is tasked with analyzing public problems and making staff reviews according to their respective fields.

In addition to the factors of communication, resources, disposition and bureaucratic structure in accordance with the theory of policy implementation put forward by Edward III [7], the research findings also found that there are other dimensions that contribute to the success of policy implementation regarding the role of the Bandung Mayor's Expert Staff, namely ) politics. This political factor arose from the results of an interview with one of the expert staff who felt that the support given by the leadership to the expert staff to carry out their duties was still lacking. In addition, even though there is an Expert Staff of the Mayor of Bandung to analyze city problems, the Mayor of Bandung has formed a Public Policy Advisory Team with members from the private sector, and the Mayor's Policy Advisory Team consisting of senior civil servants who are not accommodated in structural positions.

In accordance with the theory put forward by Nugroho [1], politics may appear in policy implementation. Grindle develops a conceptual and framework of thought regarding implementation as a political process and an administrative process. Grindle states that the success of policy implementation will be determined by 2 (two) variables, namely the content and context variables. The content variable is related to what is in public policy, while the context variable is related to how the political context and administrative activities affect the implemented policy. This context variable includes 3 (three) elements, namely the elements of power, interests and strategies of the actors involved; regime and institutional characteristics; and willingness and responsiveness. Suwitri [9] states that if political forces feel an interest in a program, they will formulate a strategy to win the competition that occurs in implementation, so that the output of a program can be enjoyed.

Purwanto and Sulistyastuti [6] say that the implementation of a policy or program is not done in a vacuum. Implementation occurs in an area in which various factors 
exist, such as geographical, social, economic and political conditions. Among these factors, political factors are considered to have the most dominant influence. Furthermore, Torenviled and Thomson in Purwanto and Sulistyastuti [6] mention that there is political bargaining in the implementation process. Political bargaining is a reality that cannot be avoided when the implementation process occurs in the public sphere that supports hatarogeneous interests. This theory further supports the possibility of political influence in policy implementation on the Role of the Bandung Mayor's Expert Staff.

\section{CONCLUSION}

The results of the study concluded that the implementation of the role of the Mayor's Expert Staff in supporting the strengthening of policy analysts at the Bandung City Government has not been running optimally. Although conceptually the Bandung Mayor's Expert Staff plays a role as policy analysts in the Bandung City Government, the reality on the ground shows a negative view of the role of the Bandung Mayor's Expert Staff. This view emerged due to the absence of a significant outcome or impact from the role of the Bandung Mayor's Expert Staff. The absence of a policy outcome in the policy regarding the role of the Bandung Mayor's Expert Staff shows that the policy objectives are not achieved. The failure to achieve this policy objective is the justification for the inadequate implementation of the role of the Bandung Mayor's Expert Staff in supporting the strengthening of the role of expert staff as policy analysts.

\section{REFERENCES}

[1] R. Nugroho, Public Policy. Jakarta: PT. Elex Media Komputindo, 2014

[2] S. Sutarto, Organizational Basics. Yogyakarta: Gadjah Mada University Press, 2006.

[3] S. Soenarko, Public Policy, Basic Understanding and Analysis of Government Policy. Surabaya: CV. Papyrus, 1998.

[4] B. Winarno, Public Policy: Theory and Process. Yogyakarta: Media Pressindo, 2008.

[5] S.A. Wahab, Analysis of Policy from Formulation to Implementation of State Policy. Jakarta: Earth Literacy, 2012.

[6] E.A. Purwanto and D.R. Sulistyastuti, Public Policy Implementation, Concept and Its Application in Indonesia. Yogyakarta: Gava Media, 2012.

[7] G.C. Edward III, Implementing Public Policy. Washington: Congressional Quarterly Press, 1980.

[8] I. Satibi, Thesis, Thesis \& Dissertation Writing Techniques. Bandung: clear, 2011.

[9] S. Suwitri, Basic Concepts of Public Policy. Semarang: Diponegoro University, 2008. 